8. HUTTO, R. L., S. M. PLETSCHET, and P. HENDRICKS. 1986. A fixed-radius point count method for nonbreeding and breeding season use. Auk 103:593-602.

9. JOHNSON, D. H. 1996. Effects of fire on bird populations in mixed-grass prairie. In: Knopf, F. L. and F. B. Samson (eds.). Ecology and Conservation of Great Plains Vertebrates. Springer, New York. p. 181-206.

10. JOHNSON, D. H., and L. D. IGL. 2001. Area requirements of grassland birds: a regional perspective. Auk 118:24-34.

11. JOHNSON, D. H., L. D. IGL, J. A. DECHANT, C. M. GOLDADE, M. L. SONDREAL, B. R. EULISS, and A. L. ZIMMERMAN. 1999. Effects of Management Practices on Grassland Birds. U.S. Geological Survey, Biological Resources Division-Northern Prairie Wildlife Research Center, Jamestown, North Dakota.

12. MADDEN, E. M., A. J. HANSEN, and R. K. MURPHY. 1999. Influence of prescribed fire history on habitat and abundance of passerine birds in northern mixed-grass prairie. Canadian FieldNaturalist 113:627-640.

13. MADDEN, E. M., R. K. MURPHY, A. J. HANSEN, and L. MURRAY. 2000. Models for guiding management of prairie bird habitat in northwestern North Dakota. American Midland Naturalist 144:377-392.

14. SAUER, J. R., J. E. HINES, and J. FALLON. 2001. The North American Breeding Bird Survey, Results and Analysis 1966 - 2001. Version 2001 .2, USGS Patuxent Wildlife Research Center, Laurel, Maryland.

15. STEWART, R. E. 1975. Breeding birds of North Dakota. Tri-college Center for Environmental Studies, Fargo, North Dakota.

16. U.S. FISH AND WILDLIFE SERVICE. 1995. Migratory nongame birds of management concern in the United States: the 1995 list. U.S. Fish and Wildlife Service, Office of Migratory Bird Management, Washington, D.C.

\title{
RURAL BANDERS IN THE YORKTON AREA*
}

\section{STUART HOUSTON, 863 University Drive, Saskatoon, SK S7N 0J8}

Of the six early banders active within the Yorkton - Duck Mountain (YDM) bird area, Judge J.A.M. Patrick, who banded from 1929 to 1933 , was the first. ${ }^{2}$ In 1937, Bill and Lindsay Wotherspoon banded 885 birds of 42 species, with 12 recoveries, in the village of Hyas and on their farm on the north side of that village." Three "outside" banders visited the YDM area in the 1940s: Fred
Bard, of the Saskatchewan Natural History Museum, released 11 banded magpies and 13 crows as part of his crow and magpie campaign. ${ }^{3}$ R. Lorne Scott banded 19 Great Horned Owls, 19 Red-tailed Hawks, 6 Blackbilled Magpies, 756 Tree Swallows and 425 Mountain Bluebirds along his bird box trail on Highway 35 , within the western boundary of the YDM area. ${ }^{4}$ J.A. Briggs of Regina 
banded 126 birds of 11 species, including 63 flickers and 7 Brewer's Blackbirds, as he inspected the Canadian National Railways track near Melville. ${ }^{5}$ Two additional banders, Robert Blakeley and Emma Wickencamp, who lived only about $10 \mathrm{~km}$ apart between Canora and Sturgis, are the topic of this brief report.

Robert Maurice Blakeley, banding permit 00164 , grew up on a farm near Tadmore, where much of his banding was done in 1929. At a farm near Wishart barely within the western boundary of the Yorkton - Duck Mountain area, and near Canora other birds were banded:Yellow-shafted Flickers, Barn Swallows and Loggerhead Shrikes. He paid a holiday visit to Carlyle Lake on 11 July where he banded two young Red-necked Grebes. From 13 to 15 August, he operated a home-made funnel trap at a slough edge near Canora where he caught four Killdeer, two Wilson's Snipe, two Solitary Sandpipers and one each of Pectoral and Least sandpipers. Vesper and Song sparrows were banded in their nests, as were American Robins, which used a variety of nest sites: a farm binder, a road bridge, a school, the railroad bridge at Sturgis, and an unspecified site in the town of Canora. His Saskatchewan banding totaled 82 individuals of 18 species.

Blakeley attended the Manitoba Agricultural College from 1931 to 1933, and had summer employment at the Morden Experimental Farm in Manitoba in 1931 and 1932, where 40 individuals of 4 species were banded, including 29 American Robins.

He had two Texas recoveries, one in October 1929 and one in February 1932, from three Red-tailed Hawks banded on the farm at Tadmore on 13 June 1929.

Mrs. Emma Wickencamp, banding permit 00285 , was a rural school teacher before she married Frank Wickencamp, whose family had moved from Nebraska in 1920 to buy the northwest quarter of section 31 , township 33, range 3 . Their farm home was on the "back road" from Sturgis to Crystal Lake, adjacent to a beautiful, small lake, $1.5 \mathrm{~km}$ south and $3 \mathrm{~km}$ west of Stenen. Emma banded birds from 1933 through 1939, banded no birds in 1940 and gave up her permit in April 1941. She died in 1969, ten years after they had left their farm.

She banded 207 individuals of 28 species. From these she had a prodigious nine recoveries: a Red-tailed Hawk shot at Buffalo Bayou, Texas, in its first migration south; the only Mallard she banded was shot at LaFleche, Saskatchewan the next year; three of eight Brewer's Blackbirds were recovered locally the same year and a fourth was shot with a slingshot by a farm lad near Canora in May two years later; an American Robin, a Downy Woodpecker, and a Black-capped Chickadee were found locally.

\section{Acknowledgements}

I thank Pat Armstrong of Sturgis (now in Saskatoon) and Richard Wickencamp of Edmonton, for personal information.

1. HOUSTON, C.S. 1945. Saskatchewan bird banders: Bill and Lindsay Wotherspoon. Blue Jay 3:16.

2. HOUSTON, C.S. 1967. Saskatchewan bird banders: Judge J.A.M. Patrick. Blue Jay 25:172-174.

3. HOUSTON, C.S. 1970. Saskatchewan bird banders: Fred G. Bard. Blue Jay 28:150156.

4. HOUSTON, C.S. 1990. Saskatchewan bird banders: R. Lorne Scott. Blue Jay 48:126-129.

5. HOUSTON, .C.S. 2003. Saskatchewan bird banders: J.A. Briggs. Blue Jay 61: (in press).

* Number 21 in a series of biographies of Saskatchewan bird banders 